\title{
Oxidant Injury of Cells \\ DNA Strand-breaks Activate Polyadenosine Diphosphate-ribose Polymerase and Lead to Depletion of Nicotinamide Adenine Dinucleotide
}

Ingrid U. Schraufstatter, Daniel B. Hinshaw, Paul A. Hyslop, Roger G. Spragg, and Charles G. Cochrane

Department of Immunology, Scripps Clinic and Research Foundation, La Jolla, California 92037;

and Department of Medicine, Pulmonary Division, University of California at San Diego Medical Center,

San Diego, California 92103

\section{Abstract}

To determine the biochemical basis of the oxidant-induced injury of cells, we have studied early changes after exposure of P388D murine macrophages to hydrogen peroxide. Total intracellular $\mathrm{NAD}^{+}$levels in $\mathrm{P388D}_{1}$ cells decreased with $\mathrm{H}_{2} \mathrm{O}_{2}$ concentrations of $40 \mu \mathrm{M}$ or higher. Doses of $\mathrm{H}_{2} \mathrm{O}_{2}$ between 0.1 and $2.5 \mathrm{mM}$ led to an $80 \%$ depletion of NAD within 20 min. With doses of $\mathrm{H}_{2} \mathrm{O}_{2}$ of $250 \mu \mathrm{M}$ or lower, the fall in NAD and, as shown previously, ATP, was reversible. Higher doses of $\mathrm{H}_{2} \mathrm{O}_{2}$ that cause ultimate lysis of the cells, induced an irreversible depletion of NAD and ATP.

Poly-ADP-ribose polymerase, a nuclear enzyme associated with DNA damage and repair, which catalyzes conversion of NAD to nicotinamide and protein-bound poly-ADP-ribose, was activated by exposure of the cells to concentrations of $40 \mu M$ $\mathrm{H}_{2} \mathrm{O}_{2}$ or higher. Activation of poly-ADP-ribose polymerase was also observed in peripheral lymphocytes incubated in the presence of phorbol myristate acetate-stimulated polymorphonuclear neutrophils. Examination of the possibility that DNA alteration was involved was performed by measurement of thymidine incorporation and determination of DNA single-strand breaks (SSB) in cells exposed to $\mathrm{H}_{2} \mathrm{O}_{2} \cdot \mathrm{H}_{2} \mathrm{O}_{2}$ at $40 \mu \mathrm{M}$ or higher inhibited DNA synthesis, and induced SSB within less than $30 \mathrm{~s}$.

These results suggest that DNA damage induced within seconds after addition of oxidant may lead to stimulation of polyADP-ribose polymerase, and a consequent fall in NAD. Excessive stimulation of poly-ADP-ribose polymerase leads to a fall in NAD sufficient to interfere with ATP synthesis.

\section{Introduction}

$\mathrm{H}_{2} \mathrm{O}_{2}$ in concentrations achieved in the proximity of stimulated neutrophils and macrophages, induces cell lysis of target cells over a period of several hours, as was shown for a number of different cell types (1-6). Various biochemical changes occur long before the loss of cell integrity. In sequential order these are the activation of the hexose monophosphate shunt (HMPS), ${ }^{1}$

This article is publication No. 3978-IMM from the Research Institute of Scripps Clinic.

Received for publication 22 July 1985.

1. Abbreviations used in this paper: $\mathrm{ACD}$, acid citrate dextrose; $\mathrm{BCNU}$, (1,3-bis)2-chlorethyl $l$-nitroso-urea; BSO, buthionine sulfoximine, HMPS, hexose monophosphate; HPLC, high pressure liquid chromatography; MGB, modified Gey's buffer; SSB, single-strand breaks; TLC, thin layer chromatography.

J. Clin. Invest.

(C) The American Society for Clinical Investigation, Inc. 0021-9738/86/04/1312/09 \$1.00

Volume 77, April 1986, 1312-1320 which provides reducing equivalents to oxidized glutathione (2, 7), inhibition of the glycolytic pathway (8) with loss of intracellular ATP $(1,9)$, increase in intracellular $\mathrm{Ca}^{++}$and $\mathrm{Na}^{+}$(Hyslop, P. A., D. B. Hinshaw, I. U. Schraufstatter, L. A. Sklar, R. G. Spragg, and C. G. Cochrane, manuscript submitted for publication; and ref. 10), aggregation of actin-rich filaments in the cytoskeleton (12), cell blebbing $(11,12)$, and cell lysis $(2-4)$.

Since ATP is essential to many cell functions, we sought to determine the basis of its depletion in $\mathrm{P}_{388 \mathrm{D}_{1} \text { murine macro- }}$ phages. Stimulation of the HMPS was calculated to account for $\sim 15 \%$ of the fall in ATP, but the remainder of the depletion was unexplained. The earlier, preliminary observation that NAD

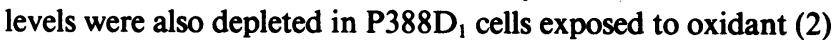
was of potential importance since low NAD levels have been associated for many years with an inhibition of the glycolytic pathway and ATP formation $(13,14)$.

The catabolism of NAD is known to be regulated by two enzymes, nuclear poly-ADP-ribose polymerase and cytoplasmic NAD glycohydrolase (15). NAD glycohydrolase forms free ADPribose, which we did not detect in $\mathrm{H}_{2} \mathrm{O}_{2}$ injured cells.

We therefore examined the possibility that activation of polyADP-ribose polymerase was responsible for the loss of NAD and ATP in P388D 1 cells exposed to $\mathrm{H}_{2} \mathrm{O}_{2}$.

\section{Methods}

Cell culture. $\mathrm{P} 388 \mathrm{D}_{1}$ murine macrophages were grown to confluence in RPMI 1640 (Irvine Scientific, Santa Ana, CA), supplemented with 10\% fetal calf serum (Hyclone Laboratories, Logan, UT), 2 mM L-glutamine, and $50 \mu \mathrm{g} / \mathrm{ml}$ gentamycin sulfate (MA Bioproducts, Walkersville, MD). Just before the experiment they were removed with a rubber policeman, centrifuged at $400 \mathrm{~g}$ for $5 \mathrm{~min}$, and resuspended in full medium or modified Gey's buffer (MGB) containing $147 \mathrm{mM} \mathrm{NaCl}, 5 \mathrm{mM} \mathrm{KCl}, 1.9$ $\mathrm{mM} \mathrm{KH} \mathrm{PO}_{4}, 1.1 \mathrm{mM} \mathrm{Na}_{2} \mathrm{SO}_{4} \cdot 7 \mathrm{H}_{2}, 5.5 \mathrm{mM}$ glucose, $1.5 \mathrm{mM} \mathrm{CaCl}$, $0.3 \mathrm{mM} \mathrm{MgSO} 4 \cdot 7 \mathrm{H}_{2} \mathrm{O}$, and $1 \mathrm{mM} \mathrm{MgCl} \cdot 6 \mathrm{H}_{2} \mathrm{O}$, and $10 \mathrm{mM}$ Hepes, pH 7.4.

Human peripheral lymphocytes were prepared from fresh acid citrate dextrose (ACD) blood after removal of platelet-rich plasma on lymphocyte separation medium (Litton Bionetics, Kensington, MD) (16). Contaminating erythrocytes were lysed in $154 \mathrm{mM} \mathrm{NH}_{4} \mathrm{Cl}, 12 \mathrm{mM} \mathrm{NaH}_{2} \mathrm{CO}_{3}$, $0.1 \mathrm{mM} \mathrm{Na} \mathrm{N}_{2}$ EDTA, pH 7.4, and the cells were washed two times in MGB. They were $95 \%$ mononuclear cells, and $95 \%$ viable.

Human polymorphonuclear neutrophils (PMN) were prepared from fresh ACD blood by counterflow centrifugal elutriation as previously described (18). The cell preparation was $98 \%$ pure, and at least $98 \%$ viable.

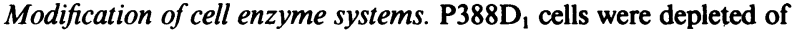
glutathione by incubation with $0.2 \mathrm{mM}$ buthionine sulfoximine (BSO) (Chemalog, Chemical Dynamics Corp., S. Plainfield, NJ) for $18 \mathrm{~h}$ (18). Inhibition of glutathione reductase was achieved by incubation with 75 $\mu \mathrm{M}$ (1,3-bis)2-chloroethyl l-nitroso-urea (BCNU) (Bristol Laboratories, Syracuse, NY) (19) for $20 \mathrm{~min}$ at $37^{\circ} \mathrm{C}$, which reduced glutathione reductase activity by $>98 \%$. 
Poly-ADP-ribose polymerase activity was inhibited by incubating P388D cells with $2.5 \mathrm{mM}$ 3-aminobenzamide (Sigma Chemical Co., St. Louis, MO) (21), which was added 10 min before the addition of oxidant. Determination of nucleotides and nucleosides by HPLC. $2.5 \times 10^{7}$ P388D 1 cells were incubated in $12.5 \mathrm{ml}$ MGB or full RPMI 1640 medium for various times with the addition of $\mathrm{H}_{2} \mathrm{O}_{2}$ as indicated in the legends. The exposure of $\mathrm{H}_{2} \mathrm{O}_{2}$ was stopped by addition of $15,000 \mathrm{U}$ catalase, and the cells were centrifuged at $1,000 \mathrm{~g}$ for $90 \mathrm{~s}$ at $4^{\circ} \mathrm{C}$. The supernatant was removed and the cell pellet was resuspended in $500 \mu 18 \%$ perchloric acid. The $\mathrm{pH}$ was adjusted to $\sim 5.5$ by removal of the perchloric acid with Freon/alamine (21). NADH and NADPH were completely degraded under these conditions (22). Cell extracts corresponding to $5 \times 10^{6}$ cells were applied to an anion exchange high pressure liquid chromatography (HPLC) column (Ultrasil AX anion exchange column, Altex Scientific, Inc., Berkeley, CA) and eluted with a gradient from $7 \mathrm{mM} \mathrm{NH}_{4} \mathrm{H}_{2} \mathrm{PO}_{4}$, pH 3.8 to $250 \mathrm{mM} \mathrm{NH}_{4} \mathrm{H}_{2} \mathrm{PO}_{4}, 500 \mathrm{mM} \mathrm{KCl}, \mathrm{pH} 4.5$ (22).

$500 \mu \mathrm{l}$ of supernatant from $5 \times 10^{6}$ cells $/ \mathrm{ml}$ were precipitated with $50 \mu \mathrm{l}$ of $70 \%$ perchloric acid, the perchloric acid was removed, and 200 $\mu \mathrm{l}$ of the sample were applied to a C18 reverse-phase HPLC column (DuPont, Wilmington, DE). Nucleosides were separated with a linear gradient from 88 to $99 \%$ buffer A (buffer A, $10 \mathrm{mM} \mathrm{KH}_{2} \mathrm{PO}_{4}, \mathrm{pH} 3.3$; buffer $\mathrm{B}, 10 \mathrm{mM} \mathrm{KH}_{2} \mathrm{PO}_{4}, \mathrm{pH} 4.0$ in $60 \%$ acetonitrile) at a flow rate of $1.5 \mathrm{ml} / \mathrm{min}$ for $25 \mathrm{~min}(23)$.

Determination of ${ }^{14} C$-nicotinamide moiety in $P 388 D_{1}$ cells. $5 \times 10^{6}$ cells/ml in the presence or absence of $\mathrm{H}_{2} \mathrm{O}_{2}$ were incubated with $1 \mu \mathrm{Ci}$ ${ }^{14} \mathrm{C}$-nicotinamide $(55 \mathrm{mCi} / \mathrm{mmol}$, Amersham Corp., Arlington Heights, IL) at $37^{\circ} \mathrm{C}$ for $30 \mathrm{~s}$ to $1 \mathrm{~h}$. At the conclusion of experiments as noted in Results, $200 \mu$ l of cell suspension were layered on top of $150 \mu$ l silicone oil (four parts Dow Corning 550, one part Dow Corning 200; William Nye, New Bedford, MA) and centrifuged for $10 \mathrm{~s}$ at $10,000 \mathrm{~g}$. The cell pellets were solubilized in $750 \mu \mathrm{l} 2 \%$ SDS in $0.1 \mathrm{M} \mathrm{NaOH}$ overnight, sonicated, and counted in a liquid scintillation counter.

For separation of different pyridine compounds the radiolabeled cells were centrifuged through silicone oil into a layer of $50 \mu \mathrm{l}$ of $250 \mathrm{mM}$ mannitol, $2.5 \mathrm{mM}$ EDTA, and $17 \mathrm{mM}$ MOPS, pH 7.4; the cell pellet was incubated in $200 \mu \mathrm{l}$ of $70 \%$ ethanol in $10 \mathrm{mM}$ sodium phosphate buffer, pH 7.0 for $30 \mathrm{~min}$ at room temperature (24). The cell extract after centrifugation was applied to thin layer chromatography (TLC) silica plates (HPTLC silica 60; Merck, Darmstadt, W. Germany), and pyridine compounds were separated as described $(2,25)$. Pyridines were quantified by scintillation counting.

Determination of DNA and protein synthesis. $2 \times 10^{6} \mathrm{P}_{388 \mathrm{D}_{1}}$ cells in full culture medium containing $0.38 \mathrm{mM}$ leucine were incubated for $1 \mathrm{~h}$ with concentrations of $\mathrm{H}_{2} \mathrm{O}_{2}$ between 10 and $1,000 \mu \mathrm{M}$ in the presence of $1 \mu \mathrm{Ci}\left[{ }^{3} \mathrm{H}\right]$ leucine $(120 \mathrm{Ci} / \mathrm{mol}, \mathrm{ICN})$ and $0.25 \mu \mathrm{Ci}{ }^{14} \mathrm{C}$-thymidine $(57$ $\mathrm{mCi} / \mathrm{mmol}, \mathrm{ICN})$. The cells were centrifuged, the supernatant was removed, and the cell pellets were resuspended in $500 \mu \mathrm{l} 50 \% \mathrm{TCA}$, followed by three washes with TCA. The TCA precipitate was solubilized as described for pyridine nucleotides, and radioactivity was measured in a liquid scintillation counter.

Determination of uptake of leucine and aminoisobutyric acid. $5 \times 10^{6}$ $\mathrm{P}_{388 \mathrm{D}_{1}}$ cells $/ \mathrm{ml}$ were incubated in full medium with concentrations of $\mathrm{H}_{2} \mathrm{O}_{2}$ between 100 and $2,000 \mu \mathrm{M}$ in the presence of $1 \mu \mathrm{Ci}\left[{ }^{3} \mathrm{H}\right]$ leucine and $2 \mu \mathrm{Ci}\left[{ }^{14} \mathrm{C}\right]$ aminoisobutyric acid $(53 \mathrm{mCi} / \mathrm{mmol}$, New England Nuclear, Boston, MA). The final concentration of leucine or amino isobutyric acid was $0.38 \mathrm{mM}$. Uptake of radiolabel was determined by centrifuging $200 \mu \mathrm{l}$ of cell suspension through $150 \mu$ l silicone oil as described for radiolabeled nicotinamide moiety, and counting the radioactivity of the cell pellet.

Determination of DNA single-strand breaks (SSB). The formation of SSB in DNA was measured by alkaline unwinding and determination of ethidium bromide fluorescence on an SLM 8000 fluorometer with excitation at $520 \mathrm{~nm}$ and emission at $590 \mathrm{~nm}$ according to the method of Birnboim and Jevcak (26). Under the conditions employed, ethidium bromide binds preferentially to double-stranded DNA. $\mathrm{H}_{2} \mathrm{O}_{2}$ was added to $2 \times 10^{6} \mathrm{P} 388 \mathrm{D}_{1}$ cells $/ \mathrm{ml}$ and the cells were incubated at $37^{\circ} \mathrm{C}$ for 5 min, centrifuged for $10 \mathrm{~s}$ in a microfuge, resuspended in $250 \mathrm{mM}$ mesoinositol, $10 \mathrm{mM}$ sodium phosphate, $1 \mathrm{mM} \mathrm{MgCl}$ ( $\mathrm{pH} 7.2$ ), and processed as described except that the alkaline lysates were incubated for $45 \mathrm{~min}$ at $15^{\circ} \mathrm{C}$. Results are expressed as $\mathrm{D}$ (percent double-stranded DNA) $=\left(F-F_{\min }\right) /\left(F_{\max }-F_{\min }\right) \times 100$, where $F$ is the fluorescence of the sample, $F_{\min }$ the background fluorescence determined in samples that were sonicated at the beginning of the unwinding period in order to induce maximal unwinding, and $\mathrm{F}_{\max }$ is the fluorescence of samples kept at $\mathrm{pH} 11.0$, which is below the $\mathrm{pH}$ needed to induce unwinding of single stranded DNA.

Determination of HMPS activity. HMPS activity was determined by subtracting ${ }^{14} \mathrm{CO}_{2}$ formed from $\mathrm{C}_{6}$-labeled glucose from ${ }^{14} \mathrm{CO}_{2}$ formed from $\mathrm{C}_{1}$-labeled glucose as previously described (2).

Determination of poly-ADP-ribose-polymerase activity. $2 \times 10^{6}$ $\mathrm{P} 388 \mathrm{D}_{1}$ cells or $5 \times 10^{6}$ human peripheral lymphocytes were incubated at $37^{\circ} \mathrm{C}$ for various periods of time in the presence or absence of $\mathrm{H}_{2} \mathrm{O}_{2}$. To stop the reaction, we centrifuged the cells at $10,000 \mathrm{~g}$ for $10 \mathrm{~s}$, removed the supernatant, and resuspended the cell pellet in $500 \mu \mathrm{l} 56 \mathrm{mM}$ Hepes buffer, $\mathrm{pH} 7.5$, containing $28 \mathrm{mM} \mathrm{KCl}, 28 \mathrm{mM} \mathrm{NaCl}, 2 \mathrm{mM} \mathrm{MgCl}$, $0.01 \%$ digitonin, and $125 \mathrm{nmol}$ NAD spikes with $0.25 \mu \mathrm{Ci}{ }^{3} \mathrm{H}-\mathrm{NAD}(22$ $\mu \mathrm{Ci} / \mathrm{mmol}$, ICN Pharmaceuticals, Irvine, CA) essentially as described (27). The amount of digitonin used (28) permeabilized plasma membranes leading to release of apoplasmic enzymes, but not to loss of intracellular organelles. The permeabilized cells were incubated for $5 \mathrm{~min}$ at $37^{\circ} \mathrm{C}$ as noted in Results, and the protein that was ribosylated with [ $\left.{ }^{3} \mathrm{H}\right] \mathrm{NAD}$ was precipitated with $200 \mu \mathrm{l} 50 \%$ TCA. After two washes with TCA, the protein pellet was solubilized in $2 \%$ SDS in $0.1 \mathrm{M} \mathrm{NaOH}$, incubated at $37^{\circ} \mathrm{C}$ overnight, and the radioactivity was determined by scintillation counting.

In experiments that determined the influence of PMA-stimulated PMN on TCA-precipitable ADP-ribose incorporation into lymphocytes, $5 \times 10^{6}$ lymphocytes were incubated in MGB in the presence or absence of $5 \times 10^{6} \mathrm{PMN} \pm 100 \mathrm{ng} / \mathrm{ml}$ PMA (Sigma Chemical Co.) for $30 \mathrm{~min}$ at $37^{\circ} \mathrm{C}$. Poly-ADP-ribose polymerase was determined as described above.

Separation of ADP-ribosylated proteins by HPLC. $\sim 5 \times 10^{7} \mathrm{P}_{388 \mathrm{D}_{1}}$ cells were labeled with $0.1 \mu \mathrm{Ci}\left[{ }^{14} \mathrm{C}\right]$ thymidine $/ \mathrm{ml}(57 \mathrm{mCi} / \mathrm{mmol}, \mathrm{ICN})$ in $75 \mathrm{ml}$ culture medium overnight. $5 \times 10^{6}$ washed thymidine-labeled $\mathrm{P} 388 \mathrm{D}_{1}$ cells were incubated at $37^{\circ} \mathrm{C}$ for $30 \mathrm{~min}$ in the presence or absence of $1 \mathrm{mM} \mathrm{H}_{2} \mathrm{O}_{2}$, and processed as for poly-ADP-ribose polymerase activity except that $10 \mu \mathrm{Ci}\left[{ }^{3} \mathrm{H}\right] \mathrm{NAD}$ were used. After $5 \mathrm{~min}$ incubation the cells were centrifuged at $10,000 \mathrm{~g}$ for $4 \mathrm{~min}$ at $4^{\circ} \mathrm{C}$. The cell pellet was resuspended in $400 \mu \mathrm{l} 100 \mathrm{mM} \mathrm{Na}_{2} \mathrm{SO}_{4}, 20 \mathrm{mM} \mathrm{NaH}_{2} \mathrm{PO}_{4}, \mathrm{pH} 6.8$ (buffer $\mathrm{G}$ ) and sonicated for $30 \mathrm{~s}$. $200 \mu \mathrm{l}$ of the filtered cell sonicate were applied on a TSK 250 gel filtration HPLC column (Bio-Rad Laboratories, Richmond, CA), and eluted isocratically with buffer $G$ with a flow rate of $1 \mathrm{ml} / \mathrm{min}$. Radioactivity in 20-s fractions was determined by scintillation counting.

\section{Results}

Effect of $\mathrm{H}_{2} \mathrm{O}_{2}$ on $\mathrm{NAD}$ levels of $\mathrm{P} 388 \mathrm{D}_{1}$ cells. $\mathrm{P} 388 \mathrm{D}_{1}$ cells $(2$ $\times 10^{6} / \mathrm{ml} \mathrm{MGB}$ ) were exposed to varying concentrations of $\mathrm{H}_{2} \mathrm{O}_{2}$ for the time periods shown in Fig. 1. The initial fall in NAD was maximal with a concentration of $\sim 100 \mu \mathrm{M} \mathrm{H}_{2} \mathrm{O}_{2}$ and led to a depletion of $>80 \%$ (from 1.35 to $0.18 \mathrm{nmol} / 10^{6}$ cells) of the intracellular NAD within $20 \mathrm{~min}$ (Fig. $1 \mathrm{~A}$ ). Doses as high as $5 \mathrm{mM} \mathrm{H}_{2} \mathrm{O}_{2}$ showed a similar degree of NAD depletion. The only difference was that in cells injured with $250 \mu \mathrm{M} \mathrm{H}_{2} \mathrm{O}_{2}$ or less the low NAD levels were not permanent, but NAD levels slowly recovered over a period of $\sim 2 \mathrm{~h}$. As little as $30-40 \mu \mathrm{M}$ $\mathrm{H}_{2} \mathrm{O}_{2}$ could induce a decrease in cellular NAD levels (see Fig. 5). Half-maximal depletion of NAD was achieved at $30 \mathrm{~min}$ with a dose of $\sim 50 \mu \mathrm{M} \mathrm{H}_{2} \mathrm{O}_{2}$.

If $\mathrm{P} 388 \mathrm{D}_{1}$ cells were exposed to $\mathrm{H}_{2} \mathrm{O}_{2}$ in full medium containing $7.4 \mu \mathrm{M}$ nicotinamide, there was an initial drop in cellular NAD levels comparable to that seen in MGB (Fig. $1 B$ ). Cellular NAD levels recovered considerably faster in the presence of nic- 


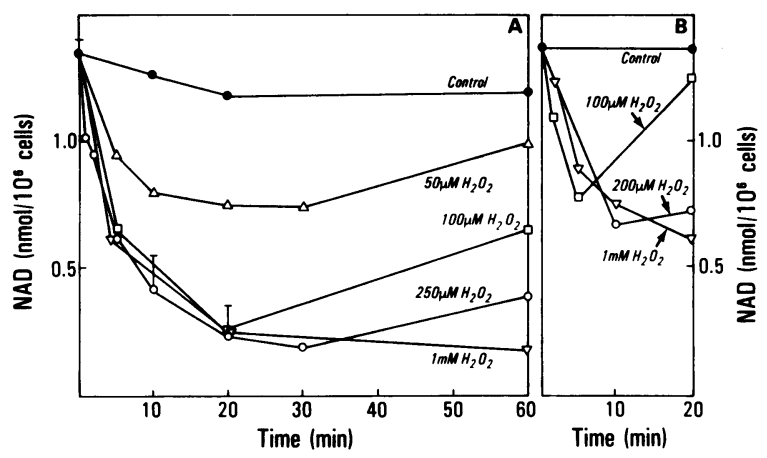

Figure 1. The effect of $\mathrm{H}_{2} \mathrm{O}_{2}$ on intracellular NAD. $2 \times 10^{6}$ cells $/ \mathrm{ml}$ were incubated in $12.5 \mathrm{ml}$ MGB $(A)$ or full medium RPMI $1640(B)$ in the absence of $\mathrm{H}_{2} \mathrm{O}_{2}(\bullet)$ or in the presence of $\mathrm{H}_{2} \mathrm{O}_{2}$ in the concentrations indicated in the figure. At the time-points indicated, catalase was added to stop the reaction and samples were prepared for HPLC nucleotide determinations as described in Methods. Each point represents the mean of two experiments. Error bars represent standard deviations for $n=4$.

otinamide, indicating that synthesis of NAD from nicotinamide was possible in the presence of $\mathrm{H}_{2} \mathrm{O}_{2}$. With doses of $\mathrm{H}_{2} \mathrm{O}_{2}$ of $500 \mu \mathrm{M}$ or higher, the drop in NAD was irreversible. The threshold dose of $\mathrm{H}_{2} \mathrm{O}_{2}$ that induced cell lysis as determined by Trypan Blue exclusion over a period of $8 \mathrm{~h}$ after addition of the oxidant was between 250 and $500 \mu \mathrm{M}$ in four experiments and thus correlates with the dose of $\mathrm{H}_{2} \mathrm{O}_{2}$ that led to irreversible NAD depletion.

NADH levels were affected to a lesser extent. With a dose of $1 \mathrm{mM} \mathrm{H}_{2} \mathrm{O}_{2}$, NADH, as measured by chemiluminescence assay (21, Calbiochem-Behring Corp., La Jolla, CA), decreased from 1.7 to $0.9 \mathrm{nmol} / 10^{6}$ cells (mean values of four experiments) over a period of $20 \mathrm{~min}$.

Human peripheral lymphocytes exposed to $250 \mu \mathrm{M} \mathrm{H}_{2} \mathrm{O}_{2}$ under the same conditions as described for $\mathrm{P}_{388 \mathrm{D}_{1}}$ cells lost 90\% of their NAD during the first 30 min of injury: NAD concentrations decreased from $0.9 \mathrm{nmol} / 10^{6}$ cells to $0.09 \mathrm{nmol} / 10^{6}$ cells.

Results obtained previously in this laboratory (1), indicated that $\mathrm{P} 388 \mathrm{D}_{1}$ cells exposed to as little as $50 \mu \mathrm{M} \mathrm{H}_{2} \mathrm{O}_{2}$ show a loss of ATP content. With a dose of $250 \mu \mathrm{M} \mathrm{H}_{2} \mathrm{O}_{2}$, the ATP levels dropped from control levels of $7.2 \mathrm{nmol} / 10^{6}$ cells to $1.9 \mathrm{nmol} /$ $10^{6}$ cells 30 min after exposure of $2 \times 10^{6} / \mathrm{ml} \mathrm{P} 388 \mathrm{D}_{1}$ cells to $\mathrm{H}_{2} \mathrm{O}_{2}$. Higher doses of $\mathrm{H}_{2} \mathrm{O}_{2}$ induced a much faster and complete reduction of ATP levels. The threshold dose of $\mathrm{H}_{2} \mathrm{O}_{2}$ required to induce a fall of ATP was slightly higher $(50 \mu \mathrm{M})$ than that for NAD $(30 \mu \mathrm{M})$ (as will be shown in Fig. 5). The changes in cellular NAD and ATP over time, were parallel (see ref. 1 for comparison).

Incorporation of $\left[{ }^{14} \mathrm{C}\right]$ nicotinamide into pyridine moiety in the presence and absence of $\mathrm{H}_{2} \mathrm{O}_{2}$. Since the fall in NAD in $\mathrm{H}_{2} \mathrm{O}_{2}$-induced injury could be partially reduced in the presence of nicotinamide, we added $\left[{ }^{14} \mathrm{C}\right]$ nicotinamide in the concentration as present in culture medium $(1 \mathrm{mg} / \mathrm{liter})$ to the incubation medium, and followed its uptake and incorporation into pyridine moiety. A linear uptake of nicotinamide during the $1 \mathrm{~h}$ of the experiment was detected in control cells (Fig. 2). The distribution of radiolabel in various pyridine moieties was measured by TLC. In control cells at $60 \mathrm{~min}, \sim 25 \mathrm{pmol}$ were present as nicotinamide, which is the amount that would be expected for any

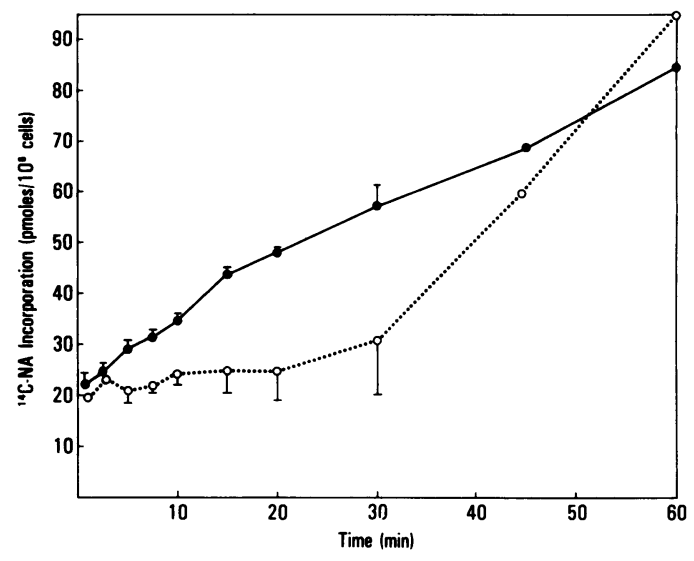

Figure 2. Uptake of ${ }^{14} \mathrm{C}$-nicotinamide in the presence and absence of $\mathrm{H}_{2} \mathrm{O}_{2} .5 \times 10^{6} \mathrm{cells} / \mathrm{ml}$ were incubated at $37^{\circ} \mathrm{C}$ in MGB in the presence (0) or absence ( $(\bullet)$ of $500 \mu \mathrm{M} \mathrm{H}_{2} \mathrm{O}_{2} .10 \mathrm{~s}$ after addition of the $\mathrm{H}_{2} \mathrm{O}_{2}, 1 \mu \mathrm{Ci}\left[{ }^{14} \mathrm{C}\right]$ nicotinamide $/ \mathrm{ml}(50 \mathrm{mCi} / \mathrm{mmol})$ was added. At the time-points indicated, $200-\mu \mathrm{l}$ samples were layered onto silicone oil and centrifuged for $10 \mathrm{~s}$ in a microfuge. Mean and SD were calculated from three experiments performed in duplicates.

freely diffusible compound, assuming a cell volume of $1 \mu \mathrm{l} / 10^{6}$ cells. 50 pmol of NAD had been synthesized during this period of time, and $\sim 5$ pmol were present as NADPH and NMN. No incorporation into NADH was observed.

In cells $\left(5 \times 10^{6} / \mathrm{ml}\right)$ exposed to $500 \mu \mathrm{M} \mathrm{H}_{2} \mathrm{O}_{2}$, no uptake of $\left[{ }^{14} \mathrm{C}\right]$ nicotinamide above the amount due to diffusion was seen until 30 min after the addition of $\mathrm{H}_{2} \mathrm{O}_{2}$. All the radioactivity incorporated up to this point was present as nicotinamide. At later time-points an increase in incorporation of $\left[{ }^{14} \mathrm{C}\right]$ nicotinamide into pyridine moiety above control levels was observed in oxidant injured cells (Fig. 2). The distribution of radiolabel at $1 \mathrm{~h}$ was identical to that seen in control cells. Therefore, the decrease in intracellular NAD concentration caused by $\mathrm{H}_{2} \mathrm{O}_{2}\left(950 \mathrm{pmol} / 10\right.$ min per $10^{6}$ cells $)$ would probably not be accounted for by inhibition of synthesis of NAD, unless the NAD turnover was considerably increased at the same time. We thus looked for nicotinamide formation from NAD as an indication for catabolism of NAD.

Detection of nicotinamide in the extracellular medium. If the

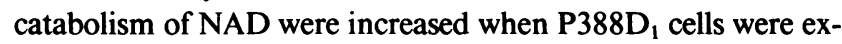
posed to $\mathrm{H}_{2} \mathrm{O}_{2}$, there should be an increase in the metabolic products, nicotinamide (NA) and ADP-ribose. We therefore assayed for the presence of these products.

Incubation of $\mathrm{P} 388 \mathrm{D}_{1}$ cells in the presence of $\mathrm{H}_{2} \mathrm{O}_{2}$ led to the appearance of nicotinamide in the extracellular medium (Fig. 3 ). The amount of nicotinamide found in the extracellular medium of $\mathrm{P}_{388 \mathrm{D}}$ cells incubated in the presence of $\mathrm{H}_{2} \mathrm{O}_{2}$ was similar to the concentration of the sum of NAD and NADH lost from the cell. After 20-min exposure to $500 \mu \mathrm{M} \mathrm{H}_{2} \mathrm{O}_{2}$, a difference of $2.2 \mathrm{nmol}$ nicotinamide was found in the extracellular medium of $\mathrm{H}_{2} \mathrm{O}_{2}$ injured and uninjured cells. At this time the injured cells had lost $1.2 \mathrm{nmol}$ NAD and $0.8 \mathrm{nmol}$ NADH.

Eukaryotic cells contain several enzymes hydrolyzing NAD that are poly-ADP-ribose polymerase, NAD glycohydrolase, and various proteins (29) that mono-ADP ribosylate elongation factor 2 , the Gs protein of the adenylate cyclase system and a mitochondrial inner membrane protein. NAD glycohydrolase forms equimolar amounts of free ADP-ribose, which elutes with a re- 


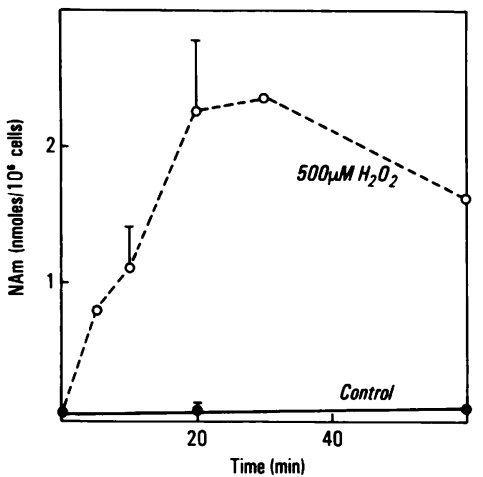

Figure 3. The effect of $\mathrm{H}_{2} \mathrm{O}_{2}$ on nicotinamide in the extracellular medium. $5 \times 10^{6}$ cells/ml were incubated at $37^{\circ} \mathrm{C}$ in MGB in the presence $(0)$ or absence $(\bullet)$ of $500 \mu \mathrm{M} \mathrm{H}_{2} \mathrm{O}_{2}$. Samples of supernatant were prepared as described in Methods and nucleosides were separated and quantitated by HPLC. Each point represents the mean of two experiments. Error bars show standard deviations for $n=3$.

tention time of $14.0 \mathrm{~min}$ in HPLC nucleotide separation. No more than traces of ADP-ribose were found in HPLC nucleotide separations. Poly-ADP-ribose polymerase forms polymers of ADP ribose which are ester-bound to nuclear proteins. Therefore we looked for changes in activity of poly-ADP-ribose-polymerase after exposure of $\mathrm{P} 388 \mathrm{D}_{1}$ cells to $\mathrm{H}_{2} \mathrm{O}_{2}$.

Determination of poly-ADP-ribose polymerase activity. PolyADP-ribose-polymerase activity was determined in $\mathrm{P}^{388 \mathrm{D}_{1}}$ cells that were incubated with $\mathrm{H}_{2} \mathrm{O}_{2}$ for various periods of time and then were treated with $0.01 \%$ digitonin in order to permeabilize them for ${ }^{3} \mathrm{H}-\mathrm{NAD}$ labeled in the adenine moiety. Binding of radiolabel to the TCA precipitable material for $5 \mathrm{~min}$ at $37^{\circ} \mathrm{C}$ was used as a measure of formation of protein-bound poly-ADPribose. Basal activity of poly-ADP-ribose polymerase was very high in control $\mathrm{P} 388 \mathrm{D}_{1}$ cells $\left(22 \pm 10 \mathrm{pmol} / 10^{6}\right.$ cells per min).

Poly-ADP-ribose polymerase activity increased at every time point between 2.5 and 60 min after exposure of $P 388 D_{1}$ cells to $1 \mathrm{mM} \mathrm{H}_{2} \mathrm{O}_{2}$ (Fig. 4). The activity was doubled from basal levels within $5 \mathrm{~min}$ of oxidant exposure, and in the presence of an excess of NAD stayed high for at least $60 \mathrm{~min}$. At this time all

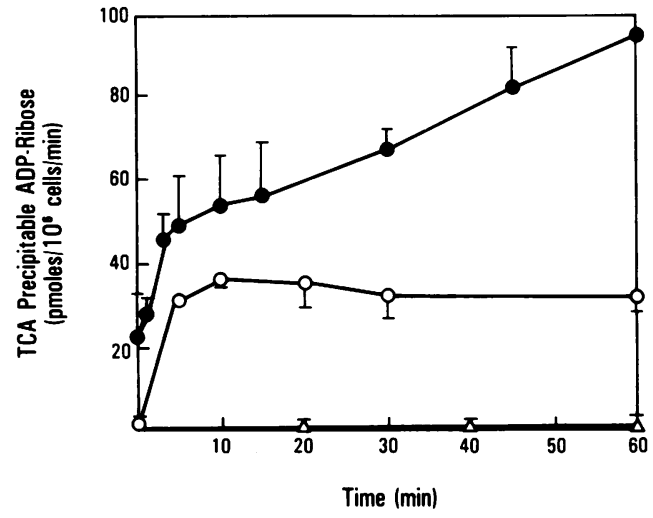

Figure 4. Time-course of poly-ADP-ribose polymerase activity after exposure to $\mathrm{H}_{2} \mathrm{O}_{2} .2 \times 10^{6} \mathrm{P} 388 \mathrm{D}_{1}$ cells/ml or $5 \times 10^{6}$ lymphocytes/ $\mathrm{ml}$ were incubated in $\mathrm{MGB} \pm \mathrm{H}_{2} \mathrm{O}_{2}$ for the periods of time indicated. At these time-points cell samples were centrifuged for $10 \mathrm{~s}$, the supernatant was removed, and the cell pellet was resuspended in $500 \mu \mathrm{l}$ lysis buffer containing $\left.{ }^{3} \mathrm{H}\right] \mathrm{NAD}$ (see Methods) and incubated at $37^{\circ} \mathrm{C}$ for $5 \mathrm{~min}$. The reaction was stopped with $200 \mu \mathrm{l} 50 \%$ TCA (mean and SD of three experiments). •, poly-ADP-ribose polymerase activity in P388D $D_{1}$ cells; $O$, poly-ADP-ribose polymerase activity in human peripheral lymphocytes; $\Delta$, poly-ADP-ribose polymerase activity in $\mathrm{P} 388 \mathrm{D}_{1}$ cells preincubated with $2.5 \mathrm{mM} 3-\mathrm{ABA}$ for $10 \mathrm{~min}$ at $37^{\circ} \mathrm{C}$

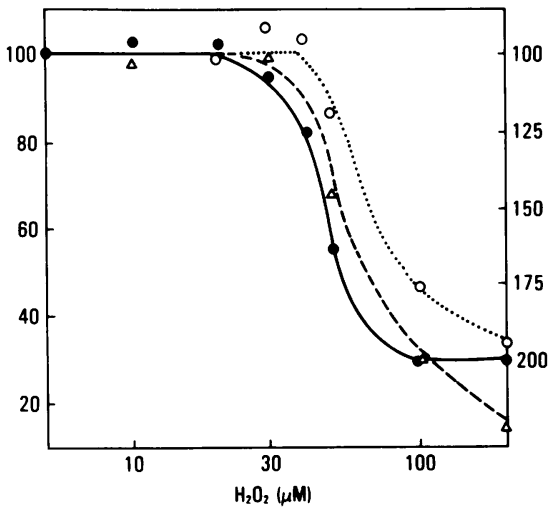

Figure 5. Response of intracellular NAD, ATP, and poly-ADP-ribose polymerase activity to varying doses of $\mathrm{H}_{2} \mathrm{O}_{2} .2 \times 10^{6} / \mathrm{ml}^{\mathrm{P} 388 \mathrm{D}_{1}}$ cells in MGB were incubated at $37^{\circ} \mathrm{C}$ in the presence of various concentrations of $\mathrm{H}_{2} \mathrm{O}_{2}$. After 20 min the cells were prepared for HPLC (NAD) (๑) and ATP (o), or $\left[{ }^{3} \mathrm{H}\right]$ NAD incorporation (poly-ADP-ribose polymerase activity) $(\Delta)$. Results (mean of 2 experiments) are expressed as percent of values found in cells incubated in the absence of $\mathrm{H}_{2} \mathrm{O}_{2}$.

but $30 \mu \mathrm{M} \mathrm{H} \mathrm{H}_{2} \mathrm{O}_{2}$ had been consumed by the cells. The doseresponse curves for $\mathrm{H}_{2} \mathrm{O}_{2}$ on NAD levels and poly-ADP-ribose polymerase activity, 20 min after addition of oxidant, are shown in Fig. 5. A minimal concentration of $30-40 \mu \mathrm{M} \mathrm{H}_{2} \mathrm{O}_{2}$ was needed to affect either of these two parameters.

Similar results were seen in human peripheral lymphocytes. Within $10 \mathrm{~min}$ after exposure to $1 \mathrm{mM} \mathrm{H}_{2} \mathrm{O}_{2}$ poly-ADP-ribose polymerase activity in these cells increased from $1.8 \pm 0.5 \mathrm{pmol} /$ $10^{6}$ cells per min to $35.9 \pm 1.6 \mathrm{pmol} / 10^{6}$ cells per min (Fig. 4).

$\mathrm{H}_{2} \mathrm{O}_{2}$ did not increase the maximal amount of ADP-riboseprotein formation in $\mathrm{P}_{388 \mathrm{D}_{1}}$ cells; when the incorporation of radiolabel from $\left[{ }^{3} \mathrm{H}\right] \mathrm{NAD}$ into acid precipitable material was followed for $30 \mathrm{~min}$, and $\mathrm{H}_{2} \mathrm{O}_{2}$ was added at this time no further increase of radioactivity occurred in the protein pellet. The initial rate of protein-bound ADP-ribose formation was doubled in cells exposed to $\mathrm{H}_{2} \mathrm{O}_{2}$.

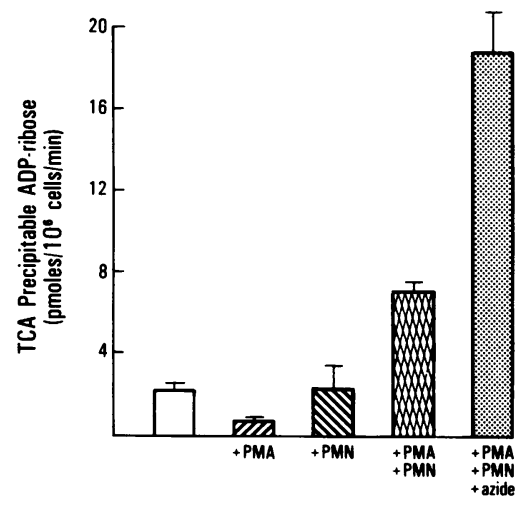

Figure 6. Poly-ADP-ribose polymerase activity in human lymphocytes exposed to PMA stimulated PMN: $5 \times 10^{6}$ peripheral human lymphocytes in $1 \mathrm{ml}$ MGB were incubated for $30 \mathrm{~min}$ at $37^{\circ} \mathrm{C}$, in the presence or absence of $5 \times 10^{6}$ human PMN, $100 \mathrm{ng}$ PMA, and $5 \mathrm{mM}$ azide as indicated in the figure. At the end of this incubation period, TCA-precipitable ADP-ribose was determined for $5 \mathrm{~min}$ at $37^{\circ} \mathrm{C}$ as described under Methods. Mean and standard deviations for duplicate samples in three experiments. 
The formation of TCA precipitable ADP-ribose polymer was reversed in the presence of snake venom phosphodiesterase (Cooper Biomedical, Malvern, PA). Only $13 \%$ of the radiolabel in control cells and $8 \%$ in cells preincubated with $1 \mathrm{mM} \mathrm{H}_{2} \mathrm{O}_{2}$ for 30 min was still found in the protein pellet, if cells that had been exposed to [ $\left.{ }^{3} \mathrm{H}\right] \mathrm{NAD}$ for $5 \mathrm{~min}$ were centrifuged, the supernatant removed, and the cells then incubated in $1 \mathrm{ml} 50 \mathrm{mM}$ TRIS, $5 \mathrm{mM} \mathrm{MgCl} 2$, pH 8.2 containing $250 \mu$ g phosphodiesterase for $60 \mathrm{~min}$ at $37^{\circ} \mathrm{C}$. No decrease in TCA precipitable material was found after DNase or RNase incubation determined as previously described (27).

We examined the target proteins of ADP-ribosylation in order to compare the sizes with those observed under other conditions. Previous studies have suggested that the major acceptor proteins for ADP-ribose are the histones, especially histone $\mathrm{Hl}$ with a molecular weight of 22,000 (30), and ADP-ribose polymerase itself with a molecular weight of 110,000 (31). This protein can be so highly ADP-ribosylated that it shows a molecular weight of up to 250,000 . In addition, high molecular weight bands with a molecular weight of $\sim 600,000$ (32) containing ADP-ribose have been shown on SDS-polyacrylamide gels. We chose a nondenaturing HPLC gel filtration method to separate $\left[{ }^{3} \mathrm{H}\right]$ ADP-ribosylated proteins. Three major peaks of radioactivity were detected (Fig. 7): a low molecular weight peak which coeluted with histone standards, a broad peak of radioactivity between 100,000 and $200,000 \mathrm{~mol} \mathrm{wt}$, which may present ribosylated poly-ADP-ribose polymerase, and a high molecular weight peak, which was associated with DNA as was shown in

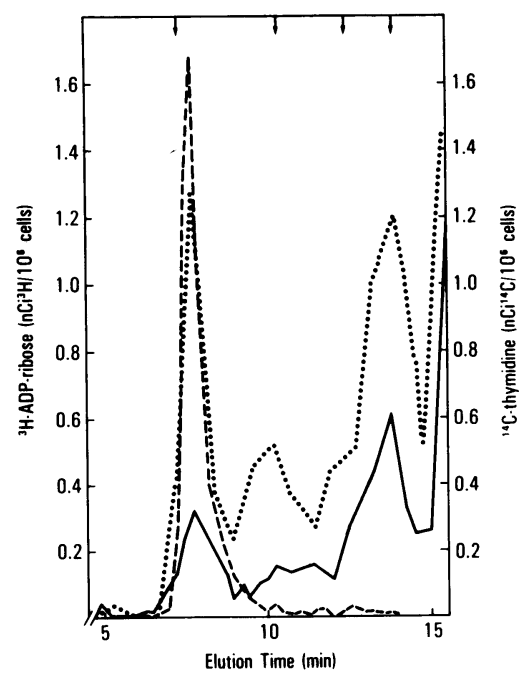

Figure 7. HPLC gel filtration elution of ADP-ribosylated proteins. Cells were labeled with $\left[{ }^{14} \mathrm{C}\right]$ thymidine $(0.1 \mu \mathrm{Ci} / \mathrm{ml})$ overnight and washed three times in MGB. $5 \times 10^{6}$ cells were incubated with or without $1 \mathrm{mM} \mathrm{H}_{2} \mathrm{O}_{2}$ for 30 in at $37^{\circ} \mathrm{C}$. After centrifugation for $10 \mathrm{~s}$, the cells were suspended in $500 \mu$ l Hepes/digitonin buffer and incubated for $10 \mathrm{~min}$ at $37^{\circ} \mathrm{C}$ in the presence of $10 \mu \mathrm{Ci}\left[{ }^{3} \mathrm{H}\right] \mathrm{NAD}$. The cells were centrifuged at $10,000 \mathrm{~g}$ for $4 \mathrm{~min}$ at $4^{\circ} \mathrm{C}$, the pellets were resuspended in $400 \mu \mathrm{l}$ HPLC running buffer, sonicated for $30 \mathrm{~s}$, and applied on a TSK 250 HPLC column. Radioactivity in 0.25 -min fractions was counted in a liquid scintillation counter. The arrows indicate the elution profile for thyroglobulin $(670,000 \mathrm{~mol} \mathrm{wt})$, gamma-globulin $(158,000 \mathrm{~mol} \mathrm{wt})$, ovalbumin $(44,000 \mathrm{~mol} \mathrm{wt})$, and myoglobin $(17,000 \mathrm{~mol} \mathrm{wt}) .(-)$, protein-bound $\left[^{3} \mathrm{H}\right] \mathrm{NAD}$ in control cells; $(\cdots \cdots)$, protein-bound $\left.{ }^{3} \mathrm{H}\right] \mathrm{NAD}$ in $\mathrm{H}_{2} \mathrm{O}_{2}$ injured cells; $(---)$, $\left[{ }^{14} \mathrm{C}\right]$ thymidine in control and injured cells.
P388D 1 cells prelabeled with $\left[{ }^{14} \mathrm{C}\right]$ thymidine. In $\mathrm{H}_{2} \mathrm{O}_{2}$-injured cells the amount of radioactivity in these three peaks was increased, while the pattern of ADP-ribosylated proteins was not detectably changed, nor was there a change in the amount of coeluting $\left[{ }^{14} \mathrm{C}\right]$ thymidine radioactivity. When $\mathrm{P} 388 \mathrm{D}_{1}$ cells were incubated with $2.5 \mathrm{mM}$ 3-aminobenzamide, an inhibitor of polyADP-ribose polymerase, for $10 \mathrm{~min}$ before the addition of 1 $\mathrm{mM} \mathrm{H} \mathrm{H}_{2} \mathrm{O}_{2}$, the rate of formation of TCA-precipitable ADPribose material dropped to $0.25 \mathrm{pmol} / \mathrm{min}$ in the presence or absence of $\mathrm{H}_{2} \mathrm{O}_{2}$. 3-Aminobenzamide did not decrease the rate of disappearance of $\mathrm{H}_{2} \mathrm{O}_{2}$ (Schraufstatter, I. U., D. B. Hinshaw, P. A. Hyslop, L. Sklar, and C. G. Cochrane, manuscript submitted for publication). It did prevent the loss of NAD in P388D cells exposed to $\mathrm{H}_{2} \mathrm{O}_{2}$ : cells pretreated with $2.5 \mathrm{mM} 3$-aminobenzamide and then exposed to $250 \mu \mathrm{M} \mathrm{H}_{2} \mathrm{O}_{2}$ for $20 \mathrm{~min}$, contained $1.8 \pm 0.1 \mathrm{nmol} \mathrm{NAD} / 10^{6}$ cells. Cells pretreated with 3ABA but not exposed to $\mathrm{H}_{2} \mathrm{O}_{2}$ contained $1.4 \pm 0.12 \mathrm{nmol} \mathrm{NAD} /$ $10^{6}$ cells.

To establish whether activation of poly-ADP-ribose polymerase occurs in the proximity of stimulated neutrophils, 5 $\times 10^{6}$ lymphocytes were coincubated with the same number of PMN in the presence or absence of 100 ng PMA. PMN do not contain poly-ADP-ribose polymerase (33). Neither PMN nor PMA alone activate poly-ADP-ribose polymer formation. PMAstimulated PMN induced a threefold increase in incorporation of $\left[{ }^{3} \mathrm{H}\right] \mathrm{NAD}$ into TCA-precipitable material in the target lymphocytes (Fig. 6). This increase in activity of poly-ADP-ribose polymerase could be further increased in the presence of azide as an inhibitor of intracellular catalase (Fig. 6).

Influence of $\mathrm{H}_{2} \mathrm{O}_{2}$ on DNA and protein synthesis. Poly-(ADPribosylation) has been associated with repair of DNA strand breaks $(31,32)$. We therefore examined the possibility that $\mathrm{H}_{2} \mathrm{O}_{2}$ treatment induced functional abnormalities of DNA function. Incorporation of $\left[{ }^{14} \mathrm{C}\right]$ thymidine and $\left[{ }^{3} \mathrm{H}\right]$ leucine into acid-insoluble material as indicators of DNA and protein synthesis was determined in $\mathrm{P}_{388 D}$ cells exposed to doses of $\mathrm{H}_{2} \mathrm{O}_{2}$ between 10 and $1,000 \mu \mathrm{M}$. Results are shown in Fig. 8. As noted, a dosedependent inhibition of both $\left[{ }^{14} \mathrm{C}\right]$ thymidine and $\left[{ }^{3} \mathrm{H}\right]$ leucine into the TCA precipitates was observed. The inhibition of $\left[{ }^{3} \mathrm{H}\right]$ leucine incorporation could not be accounted for by inhibition of amino acid transport across the membrane, since uptake of $\left[{ }^{3} \mathrm{H}\right]$ aminoisobutyric acid (an amino acid that is not incorporated into protein) was not influenced by $\mathrm{H}_{2} \mathrm{O}_{2}$ concentrations of $1 \mathrm{mM}$ or less. Higher concentrations of $\mathrm{H}_{2} \mathrm{O}_{2}$ actually caused a slight increase of uptake of amino acids.

The threshold for inhibition of the incorporation of $\left[{ }^{14} \mathrm{C}\right]$ thymidine and $\left[{ }^{3} \mathrm{H}\right]$ leucine was similar to the minimal dose that led to activation of poly-ADP-ribose polymerase and decrease in NAD levels. These data indicate a marked effect of $\mathrm{H}_{2} \mathrm{O}_{2}$ exposure to the $\mathrm{P} 388 \mathrm{D}_{1}$ cells on DNA related functions.

Influence of $\mathrm{H}_{2} \mathrm{O}_{2}$ on DNA SSB. When DNA SSB were determined 5 min after the addition of $\mathrm{H}_{2} \mathrm{O}_{2}$ by the alkaline unwinding technique, a slight increase in single-stranded DNA was observed with as little as $25 \mu \mathrm{M} \mathrm{H}_{2} \mathrm{O}_{2}$. With $100 \mu \mathrm{M} \mathrm{H}_{2} \mathrm{O}_{2}$, only $26 \%$ of the DNA was still double-stranded under our experimental conditions (Fig. 9). A similar dose response was obtained for peripheral human lymphocytes. The amount of DNA unwinding seen with $100 \mu \mathrm{M} \mathrm{H}_{2} \mathrm{O}_{2}$ in lymphocytes was equivalent to that induced in these cells by 500 rad of ${ }^{60} \mathrm{Co}$ irradiation (34).

When catalase was added to $\mathrm{P} 388 \mathrm{D}_{1}$ cells exposed to 200 $\mu \mathrm{M} \mathrm{H}_{2} \mathrm{O}_{2}$ at intervals after addition of $\mathrm{H}_{2} \mathrm{O}_{2}$, and SSB were 


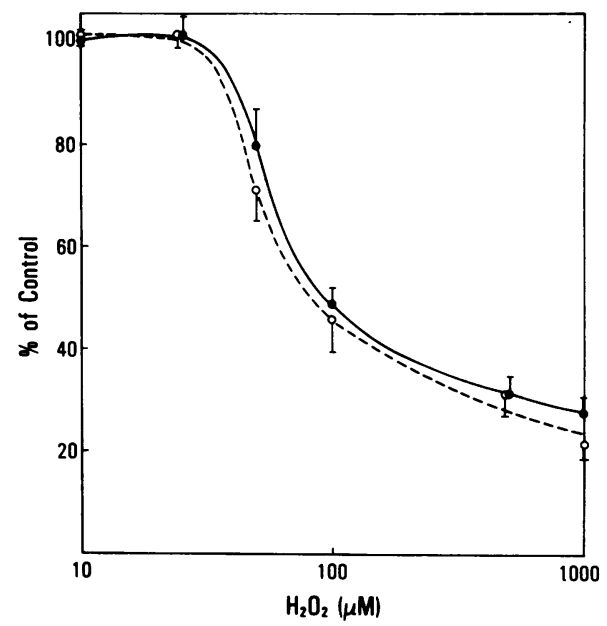

Figure 8. Influence of $\mathrm{H}_{2} \mathrm{O}_{2}$ on DNA and protein synthesis. $2 \times 10^{6}$ $\mathrm{P} 388 \mathrm{D}_{1}$ cells in full culture medium were incubated for $1 \mathrm{~h}$ with concentrations of $\mathrm{H}_{2} \mathrm{O}_{2}$ between 10 and $1,000 \mu \mathrm{M}$ in the presence of $\left[{ }^{14} \mathrm{C}\right]$ thymidine $(\mathrm{O})$ and $\left[{ }^{3} \mathrm{H}\right]$ leucine $(\bullet)$. The reaction was stopped by the addition of TCA as described in Methods. Results are expressed as percent of incorporation of radiolabel into acid-precipitable material in control cells. Mean and SD of three experiments done in duplicates.

measured in these cells it was observed that an exposure time of $10 \mathrm{~s}$ - the shortest time experimentally possible-was sufficient to induce SSB. After $10 \mathrm{~s}, 65 \%$ of the DNA was present as double-stranded DNA; after $30 \mathrm{~s}$, only $37 \%$.

Influence of HMPS activity on cellular NAD levels. Our results indicated that activation of poly-ADP-ribose polymerase played a role in $\mathrm{H}_{2} \mathrm{O}_{2}$-induced cellular injury, yet it was not the only event induced by oxidant injury.

Activation of the HMPS occurred independently of the activation of poly-ADP-ribose-polymerase. If the HMPS was inactivated (2) by either inhibiting glutathione reductase with 75 $\mu \mathrm{M}$ BCNU (19) or by depleting cellular glutathione to 7\% of the initial amount with $0.2 \mathrm{mM}$ BSO overnight (18), NAD levels in cells exposed to $\mathrm{H}_{2} \mathrm{O}_{2}$ dropped to a similar degree as in cells with an active HMPS. After 10-min incubation with $1 \mathrm{mM} \mathrm{H}_{2} \mathrm{O}_{2}$ in full medium, NAD levels in cells treated with $\mathrm{BCNU}$ were $0.65 \mathrm{nmol} / 10^{6}$ cells; in BSO treated cells, $0.68 \mathrm{nmol} / 10^{6}$ cells;

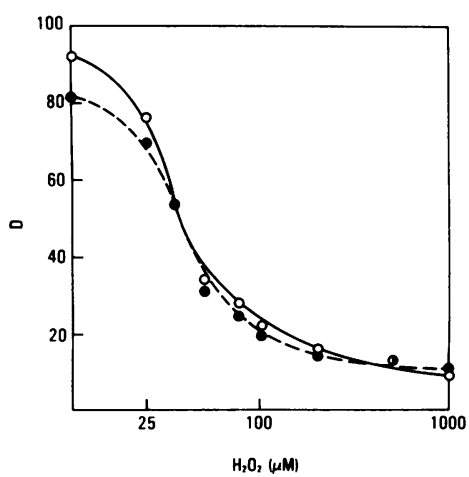

Figure 9. DNA singlestrand breaks as determined by alkaline unwinding technique. $\mathrm{P} 388 \mathrm{D}_{1}$ cells $(\bullet)$ or human peripheral lymphocytes (0) $\left(2 \times 10^{6} / \mathrm{ml} \mathrm{MGB}\right)$ were incubated with different doses of $\mathrm{H}_{2} \mathrm{O}_{2}$ for $5 \mathrm{~min}$ at $37^{\circ} \mathrm{C}, \mathrm{H}_{2} \mathrm{O}_{2}$ was removed by centrifugation, the cell pellet was resuspended in $450 \mu \mathrm{l}$ ice-cold meso-inositol buffer, and 200- $\mu$ l samples were lysed in alkaline

medium. Ethidium bromide fluorescence was determined (excitation, $520 \mathrm{~nm}$; emission, $590 \mathrm{~nm}$ ) after a $45-$ min incubation at $15^{\circ} \mathrm{C}$. D represents percent double-stranded DNA at the end of this incubation period as described in Methods. Mean of three experiments determined in duplicate. and $0.71 \mathrm{nmol} / 10^{6}$ cells in cells not treated with inhibitors of the glutathione cycle.

To determine if inhibition of the ADP-ribose polymerase affected the glutathione cycle in cells exposed to oxidant, $\mathrm{P}_{388 \mathrm{D}_{1}}$ cells were pretreated with 3-aminobenzamide before exposure to $\mathrm{H}_{2} \mathrm{O}_{2}$. BCNU or BSO had no effect on cells without exposure to $\mathrm{H}_{2} \mathrm{O}_{2}$. The HMPS activity was not influenced by inhibition of poly-ADP-ribose polymerase activity with $2.5 \mathrm{mM} 3$-aminobenzamide (Fig. 10). Exposure of $\mathrm{P}_{388 \mathrm{D}_{1}}$ cells to $2.5 \mathrm{mM}$ $\mathrm{H}_{2} \mathrm{O}_{2}$ induced an initial 10-fold increase in HMPS activity in the presence as well as in the absence of 3-aminobenzamide.

\section{Discussion}

The exposure of $P 388 D_{1}$ cells to $\mathrm{H}_{2} \mathrm{O}_{2}$ induced a fall in NAD and ATP levels starting within 1 min after its addition, which reached a maximum after $\sim 30 \mathrm{~min}$. The evidence suggested that the fall in intracellular NAD resulted from increased catabolic rate. The rate of formation of catabolic products nicotinamide and poly-ADP-ribose was increased at a time when NAD levels were falling. These data suggested that exposure to $\mathrm{H}_{2} \mathrm{O}_{2}$ leads to stimulation of the enzyme poly-ADP-ribose-polymerase. The threshold dose of $\mathrm{H}_{2} \mathrm{O}_{2}$ needed to induce a fall of NAD was identical to the minimal dose of $\mathrm{H}_{2} \mathrm{O}_{2}$ necessary to activate polyADP-ribose-polymerase.

Inhibition of poly-ADP-ribose polymerase with $2.5 \mathrm{mM} 3-$ aminobenzamide or $2.5 \mathrm{mM}$ theophylline prevented the fall in NAD induced by $\mathrm{H}_{2} \mathrm{O}_{2}$. This underscores the role of poly-ADPribose polymerase and increased catabolism of NAD as the cause of its depletion. In addition, in studies to be reported separately (Schraufstatter, I. U., D. B. Hinshaw, P. A. Hyslop, L. Sklar, and C. G. Cochrane, manuscript submitted for publication), inhibition of this enzyme was found to prevent the sustained fall in ATP, the increase in intracellular $\mathrm{Ca}^{++}$, and lysis of $\mathrm{P}_{388 \mathrm{D}_{1}}$ cells.

The fall in ATP followed closely the decrease in NAD observed either as a time-course or a dose-response relationship. Whenever intracellular NAD fell by 50\% $(0.7 \mathrm{mM})$, ATP levels started to decrease as well (Fig. 5). Similarly, when NAD levels increased again (with low concentrations of $\mathrm{H}_{2} \mathrm{O}_{2}$ of $250 \mu \mathrm{M}$ or

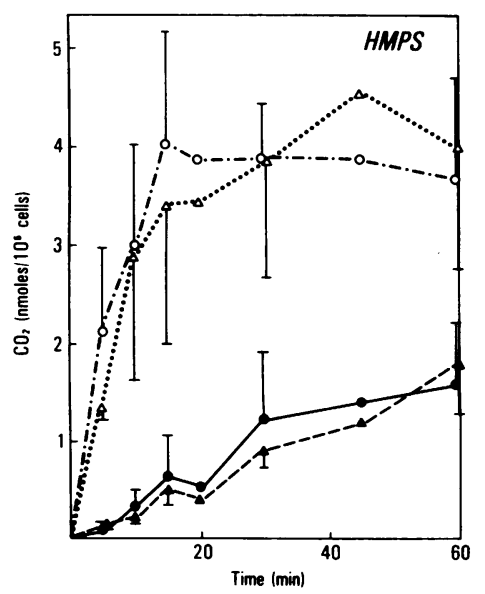

Figure 10. Influence of inhibition of poly-ADP-ribose polymerase on HMPS activity in the presence and absence of $\mathrm{H}_{2} \mathrm{O}_{2} .4 \times 10^{6}$ $\mathrm{P} 388 \mathrm{D}$, cells in $2 \mathrm{ml}$ MGB were incubated with $2 \mu \mathrm{Ci}$ $\mathrm{C}_{6}-\left[{ }^{14} \mathrm{C}\right]$ glucose or $0.5 \mu \mathrm{Ci}$ $\mathrm{C}_{1}-\left[{ }^{14} \mathrm{C}\right]$ glucose (2). For inhibition of poly-ADP-ribose polymerase, cells were preincubated with $2.5 \mathrm{mM}$ 3-aminobenzamide. 2.5 $\mathrm{mM} \mathrm{H}_{2} \mathrm{O}_{2}$ was added at the same time as the radiolabel. The reaction was stopped at the time-points indicated by

the addition of $200 \mu \mathrm{l} 50 \%$ trichloroacetic acid and $\mathrm{CO}_{2}$ was trapped on cotton swabs soaked in $\mathrm{NaOH}$. HMPS activity was calculated by subtracting ${ }^{14} \mathrm{CO}_{2}$ formed from $\mathrm{C}_{6}$-labeled glucose from ${ }^{14} \mathrm{CO}_{2}$ formed from $\mathrm{C}_{1}$-labeled glucose. 
lower), ATP concentrations started to recover as well. Note that the threshold concentration of $\mathrm{H}_{2} \mathrm{O}_{2}$ that would lead to cell lysis within 3-6 $\mathrm{h}$ was also in the $250-500-\mu \mathrm{M}$ range. Permanent energy depletion thus was incompatible with cell survival. The glycolytic pathway that generates $75 \%$ of the ATP in P388D cells (1) is inhibited in the presence of $\mathrm{H}_{2} \mathrm{O}_{2}$.

An increase in nicotinamide concentrations in the extracellular medium paralleled the depletion of NAD intracellularly. Since NADH is not a substrate for poly-ADP-ribose polymerase (15), one must assume that the NADH was lost from the cell as a result of oxidation and then conversion into nicotinamide and poly-ADP-ribose. Moreover, when poly-ADP-ribose polymerase was inhibited with $3-\mathrm{ABA}$, we observed that there was an increase in NAD of $\sim 0.8 \mathrm{nmol} / 10^{6}$ cells during the first $10 \mathrm{~min}$ in the presence of $250 \mu \mathrm{M} \mathrm{H}_{2} \mathrm{O}_{2}$ (Schraufstatter, I. U., D. B. Hinshaw, P. A. Hyslop, L. Sklar, and C. G. Cochrane, manuscript submitted for publication), which was accompanied by a similar fall in NADH levels (unpublished results).

The loss of NAD after exposure to $\mathrm{H}_{2} \mathrm{O}_{2}$ was higher than the amount of protein-bound ADP-ribose recovered and preceded the measured activation of poly-ADP-ribose polymerase. With a concentration of $1 \mathrm{mM} \mathrm{H}_{2} \mathrm{O}_{2} 350$ pmol poly-ADP-ribose bound to protein were formed during the first $10 \mathrm{~min}$ of injury; 850 pmol NAD were lost under the same conditions. The reasons for the apparent discrepancy may lie in the fact that proteinbound ADP-ribose can be further metabolized by poly-ADPribose-glycohydrolase, which hydrolyzes the ribose-ribose bond, by phosphodiesterase, which hydrolyzes the pyrophosphate bond, and by ADP-ribosyl-histone splitting enzyme $(35,36)$. ADPribose itself is further metabolized into AMP and ribose phosphate (37) (Fig. 11), which then can be used for ATP formation. The half-life of polymeric ADP-ribose has been measured by adding 3-aminobenzamide, an inhibitor of poly-ADP-ribosepolymerase, to Ehrlich ascites tumor cells, treated with alkylating agents (37), and following the disappearance of poly-ADP-ribose. The half-life under those conditions was $<1 \mathrm{~min}$. The half-life of disappearance in our cells was $\sim 5$ min for $\mathrm{H}_{2} \mathrm{O}_{2}$-injured cells and $\sim 13$ min for control cells. An increase in catabolism in poly-ADP-ribose polymer in the presence of $\mathrm{H}_{2} \mathrm{O}_{2}$ might explain the lag in time between the measured increase of poly-ADPribose polymerase activity and the loss of NAD during the first $5 \mathrm{~min}$. Similar discrepancies between loss of NAD and recovery of protein-bound ADP-ribose, determined by various methods, have been described for several other situations (37-39) that are associated with activation of poly-ADP-ribose polymerase.

The basal level of incorporation of $\left[{ }^{3} \mathrm{H}\right]$ NAD into acid pre-

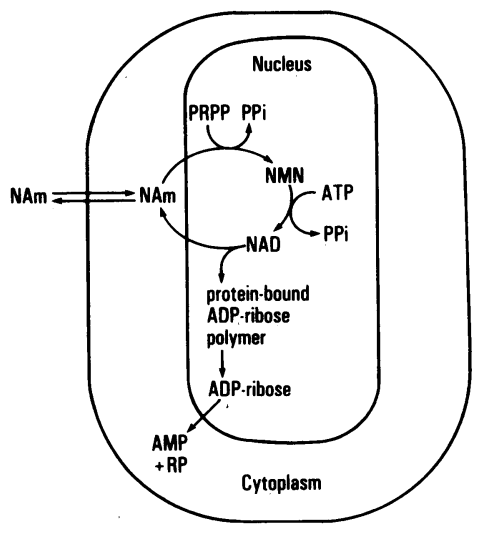

Figure 11. Synthetic and catabolic steps of polyADP-ribose metabolism. $N A m$, nicotinamide; $N M N$, nicotinamide mononucleotide; $P R P P$, phosphoribose pyrophosphate; $P P i$, pyrophosphate; $R P$, ribose phosphate. cipitable material was very high in $\mathrm{P}_{388 \mathrm{D}_{1}}$ cells, which made it difficult to measure small increases of poly-ADP-ribose polymerase activity. Human peripheral lymphocytes contain only $\sim 10 \%$ of the basal activity, but show the same absolute increase

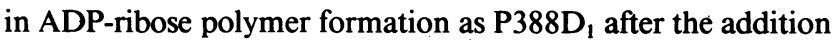
of $\mathrm{H}_{2} \mathrm{O}_{2}$ (Fig. 4). For this purpose lymphocytes were chosen as the target cells for oxidants produced by stimulated PMN. The total amount of $\mathrm{H}_{2} \mathrm{O}_{2}$ produced by $5 \times 10^{6} \mathrm{PMN}$ stimulated with $100 \mathrm{ng}$ PMA during $30 \mathrm{~min}$ averaged $50 \mathrm{nmol} / \mathrm{ml}$. Activation of poly-ADP-ribose polymerase in the target cells lymphocytes was observed under those conditions.

Poly-ADP-ribose polymerase activity is dependent on the presence of DNA $(35,36,40)$, and causes an NAD-dependent cross-linking of modified oligonucleosomes $(41,42)$. A physical association of DNA with poly-ADP-ribose was suggested in the present data in which ADP-ribose and DNA eluted together in HPLC.

Activation of poly-ADP-ribose polymerase has been described for various situations that are associated with DNA strand breaks: (a) following irradiation (43-45), $(b)$ in the presence of alkylating agents (43-49), (c) or deoxyadenosine (50), and (d) in permeabilized cells treated with DNAse (51). DNAse treatment induced activation of poly-ADP-ribose polymerase under the experimental conditions used here. Thus, the question arose whether DNA was the primary target of $\mathrm{H}_{2} \mathrm{O}_{2}$ induced injury, secondarily leading to activation of poly-ADP-ribose polymerase.

The presence of DNA SSB seen with concentrations of $\mathrm{H}_{2} \mathrm{O}_{2}$ as low as $25 \mu \mathrm{M}$ agrees with this hypothesis, especially since DNA SSB occurred within seconds after the addition of oxidant. Threshold doses of $\mathrm{H}_{2} \mathrm{O}_{2}$ needed to induce poly-ADP-ribose polymerase activation are approximately the same as those inducing DNA SSB. DNA synthesis measured during the first hour after exposure to varying doses of $\mathrm{H}_{2} \mathrm{O}_{2}$ showed a similar doseresponse as that observed for SSB. There was a linear relationship between $Q_{d}=\left(100 \times\left(\log \mathrm{D}_{\text {control }}-\log \mathrm{D} \mathrm{H}_{2} \mathrm{O}_{2}\right)\right)(34)$ determined for SSB and the percent inhibition of DNA synthesis for the range of concentrations of $\mathrm{H}_{2} \mathrm{O}_{2}$. DNA damage induced by various agents blocks semiconservative DNA synthesis, but the mechanisms involved are not well understood in eukaryotic cells (52).

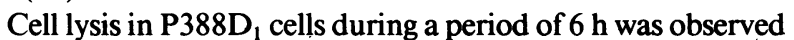
with doses of $\mathrm{H}_{2} \mathrm{O}_{2}$ of $\sim 250 \mu \mathrm{M}$ (at a cell concentration of 2 $\times 10^{6} / \mathrm{ml}$ ) and higher (2). This dose corresponds to the concentration of $\mathrm{H}_{2} \mathrm{O}_{2}$ needed to induce an irreversible loss of NAD and ATP. Considerably lower doses of $\mathrm{H}_{2} \mathrm{O}_{2}$ (threshold, $\sim 30$ $\mu \mathrm{M})$ were sufficient to transiently deplete cells of their high energy phosphates, to inhibit DNA and protein synthesis, and to induce DNA SSB. DNA alterations occurring in this low dose range of $\mathrm{H}_{2} \mathrm{O}_{2}$ might be passed on into further cell generations, unless efficient DNA repair is taking place. Recent reports have shown that concentrations of $\mathrm{H}_{2} \mathrm{O}_{2}$ that can be produced by stimulated neutrophils can induce sister chromatid exchanges in target cells (52-54) and even lead to malignant growth (55).

Activation of the glutathione redox cycle (2)-an important cellular oxidant defense mechanism $(4,56)$-measured by an increase in HMPS activity, occurred independently of the activation of poly-ADP-ribose polymerase. Inhibition of the polyADP-ribose polymerase with 3-ABA was without effect on oxidant stimulation of the glutathione cycle. The inverse experiment, inhibition of the HMPS activity, had no influence on poly-ADP-ribose polymerase activity and on cellular NAD levels, and only a minor effect on cellular ATP levels (2). 
In summary, we have shown that early in cell injury $\mathrm{H}_{2} \mathrm{O}_{2}$ can induce depletion of NAD followed by a fall in ATP due to activation of poly-ADP-ribose polymerase activation. Note, however, that this represents only one of several possible mechanisms of cell killing by oxidants. Cell lysis in cells that have a lower activity of poly-ADP-ribose polymerase (57-59) and HMPS activity, might be mediated by other mechanisms such as (a) enzyme inhibition due to oxidation and amino acids such as tryptophane, tyrosine, and the sulfhydryl containing amino acids or $(b)$ following lipid peroxidation $(60)$ or $(c)$ be the result of irreparable DNA damage such as double strand breaks.

The observation that the oxidant, $\mathrm{H}_{2} \mathrm{O}_{2}$, or an intracellular metabolite of it, induces rapid onset of DNA strand breaks at low concentrations focuses attention on the relationship of inflammation, mutagenesis and malignant transformation. This relationship has received clear experimental support recently $(53,55,61)$.

\section{Acknowledgments}

We acknowledge the excellent secretarial help from Monica Bartlett.

This work was supported in part by funds from U. S. Public Health Service (HL23584, AI17354, and HL16411), and also by a fellowship from The Puritan Bennett Foundation to Dr. Schraufstatter, a fellowship from the American Lung Association to Dr. Hinshaw, and a fellowship from the American Heart Association to Dr. Hyslop.

\section{References}

1. Spragg, R. F., D. B. Hinshaw, P. A. Hyslop, I. U. Schraufstatter, and C. G. Cochrane. 1985. Alterations in ATP and energy charge in cultured endothelial and $\mathrm{P}_{388 \mathrm{D}}$ cells following oxidant injury. J. Clin. Invest. 76:1471-1476.

2. Schraufstatter, I. U., D. B. Hinshaw, P. A. Hyslop, R. G. Spragg, and C. G. Cochrane. 1985. Glutathione cycle activity and pyridine nucleotide levels in oxidant-induced injury of cells. J. Clin. Invest. 76(3): 1131-1139.

3. Nathan, C. F., S. C. Silverstein, L. H. Brukner, and Z. A. Cohn. 1979. Extracellular cytolysis by activated macrophages and granulocytes. II. Hydrogen peroxide as a mediator of cytotoxicity. J. Exp. Med. 149: $100-113$.

4. Nathan, C. F., B. A. Arrick, H. W. Murray, N. M. DeSantis, and Z. A. Cohn. 1980. Tumor cell antioxidant defenses: inhibition of the glutathione redox cycle enhances macrophage-mediated glycolysis. $J$. Exp. Med. 158:766-788.

5. Simon, R. H., C. H. Scoggin, and D. Patterson. 1981. Hydrogen peroxide causes the fatal injury to human fibroblasts exposed to oxygen radicals. J. Biol. Chem. 256:7181-7186.

6. Weiss, S. J., J. Young, A. F. LoBuglio, and A. Slivka. 1981. Role of hydrogen peroxide in neutrophil-mediated destruction of cultured endothelial cells. J. Clin. Invest. 68:714-724.

7. Brigelius, R. 1983. Glutathione oxidation and activation of pentose phosphate cycle during hydroperoxide metabolism. Hoppe Seyler's Z. Physiol. Chem. 364:989-996.

8. Baker, N., and L. Wilson. 1963. Inhibition of tumor glycolysis by hydrogen peroxide formed from autooxidation of unsaturated fatty acids. Biochem. Biophys. Res. Commun. 11:60-64.

9. Holmsen, H., and L. Robkin. 1977. Hydrogen peroxide lowers ATP levels in platelets without altering adenylate energy charge and platelet function. J. Biol. Chem. 252:1752-1757.

10. Lotscher, H. R., K. H. Winterhalter, E. Carfori, and C. Richter. 1980. Hydroperoxide induced loss of pyridine nucleotides and release of $\mathrm{Ca}^{++}$from rat liver mitochondria. J. Biol. Chem. 255:9325-9330.

11. Hinshaw, D. B., L. A. Sklar, B. Bohl, I. U. Schraufstatter, P. A. Hyslop, M. W. Rossi, R. G. Spragg, and C. G. Cochrane. 1986. Cyto- skeletal and morphological impact of cellular oxidant injury. Am. J. Pathol. In press.

12. Orrenius, S., S. A. Jewell, G. Bellomo, H. Thor, D. P. Jones and M. T. Smith. 1983. Regulation of calcium regulation in the hepatocytea critical role of glutathione. In Functions of Glutathione: Biochemical, physiological, Toxicological and Clinical aspects. A. Larsson, S. Orrenius, A. Holmgren, and B. Mannervik, editors. Raven Press, Inc., New York. 261-273.

13. Holzer, H., and S. Frank. 1958. Zum Mechanismus der Wirkung von Rontgenstrahlen auf Krebszellen. Angew. Chem. 17:570-571.

14. Roitt, I. M. 1956. The inhibition of carbohydrate metabolism in ascites-tumour cells by ethylenimines. Biochem. J. 63:300-307.

15. McCreanor, G. M., and D. A. Bender. 1983. The role of catabolism in controlling tissue concentration of nicotinamide nucleotide coenzymes. Biochim. Biophys. Acta. 759:222-228.

16. Boyum, A. 1968. Isolation of mononuclear cells and granulocytes from human blood. Scand. J. Clin. Lab. Invest. 21:(Suppl. 97):77.

17. Berkow, R. L., D. Y. Tzeng, L. V. Williams, and R. L. Baehner. 1983. The comparative responses of human polymorphonuclear leukocytes obtained by counterflow centrifugal elutriation and Ficoll-Hypaque density centrifugation. J. Lab. Clin. Med. 102(5):732-742.

18. Griffith, O. W., and A. Meister. 1979. Potent and specific inhibition of glutathione synthesis by buthionine sulfoximine (S-n-bytylhomocysteine sulfoximine). J. Biol. Chem. 254:7558-7560.

19. Frischer, H., and T. Ahmad. 1977. Severe generalized glutathione reductase deficiency after anti-tumor therapy with BCNU [1,3-bis (chloroethyl)-l-nitro-urea]. J. Lab. Clin. Med. 89:1080-1091.

20. Paine, A. J., C. M. Allen, B. W. Durkacz, and S. Shall. 1982. Evidence that poly(ADP-ribose) polymerase is involved in the loss of NAD from cultured rat liver cells. Biochem. J. 1982. 202:551-553.

21. Khym, J. X. 1975. An analytical system for rapid separation of tissue nucleotides at low pressures on conventional anion exchanges. Clin. Chem. 21:1245-1248.

22. Pogolotti, A. L., and D. V. Santi. 1982. High-performance liquid chromatography-ultraviolet analysis of intracellular nucleotides. Anal. Biochem. 116:335-345.

23. Matsumoto, S. S., K. O. Raivio, and J. E. Seegmiller. 1979. Adenine nucleotide degradation during energy depletion in human lymphoblasts. J. Biol. Chem. 254:8956-8962.

24. Karp, M. T., R. P. Raunio, and T. N. E. Lovgren, 1983. Simultaneous extraction and combined bioluminescent assay of $\mathrm{NAD}^{+}$and NADH. Anal. Biochem. 130:335-345.

25. Heard, J. T. 1983. Thin-layer chromatographic separation of intermediates of the pyridine nucleotide cycle. Anal. Biochem. 130:185188.

26. Birnboim, H. C., and J. J. Jevcak. 1981. Fluorometric method for rapid detection of DNA strand breaks in human white blood cells produced by low doses of radiation. Cancer Res. 41:1889-1892.

27. Althaus, F. R., S. D. Lawrence, G. L. Sattler, and H. C. Pitot. 1982. ADP-ribosyltransferase activity in culture hepatocytes: interactions with DNA repair. J. Biol. Chem. 257(10):5528-5535.

28. Fiskum, G., S. W. Craig, G. L. Decker, and A. L. Lehninger. 1980. The cytoskeleton of digitonin-treated rat hepatocytes. Proc. Natl. Acad. Sci. USA. 77(6):3430-3434.

29. Ueda, K. 1985. ADP-ribosylation. Ann. Rev. Biochem. 54:73100.

30. Kawaichi, M., K. Ueda, and O. Hayaishi. 1981. Multiple autopoly (ADP-ribosyl)ation of rat liver poly (ADP-ribose) synthetase. Mode of modification and properties of automodified synthetase. J. Biol. Chem. 256:9483-9488.

31. Thi Man, N., and S. Shall. 1982. The alkylating agent, dimethyl sulphate stimulates ADP-ribosylation of histone $\mathrm{H} 1$ and other proteins in permeabilized mouse lymphoma (L 1210) cells. Eur. J. Biochem. 126: 83-88.

32. Marioka, Y., K. Tanaka, and T. Ono. 1982. Acceptors of poly (ADP-ribosyl)ation in differentiation inducer-treated and untreated Friend erythroleukemia cells. Biochim. Biophys. Acta 699:255-263.

33. Ikai, K., K. Ueda, M. Fukushima, T. Nakumura, and O. Hayaishi. 
1980. Poly (ADP-ribose) synthesis, a marker of granulocyte differentiation. Proc. Natl. Acad. Sci. USA. 77:3682-3685.

34. McWilliams, R. S., W. G. Cross, J. G. Kaplan, and H. C. Birnboim. 1983. Rapid rejoining of DNA strand breaks in resting human lymphocytes after irradiation of low doses of ${ }^{60} \mathrm{Co} \alpha$-rays. Rad. Res. 94: 499-507.

35. Benjamin, R. C., and D. M. Gill. 1980. Poly (ADP)synthesis in vitro programmed by damaged DNA. A comparison of DNA molecules containing different strand breaks. J. Biol. Chem. 255:10502-10508.

36. Smulson, M. E., and T. Sugimura. 1984. Overview of poly (ADPribosyl)ation. Methods Enzymol. 106:438-440.

37. Wielckens, K., A. Schmidt, E. George, R. Bredehorst, and H. Hilz. 1982. DNA fragmentation and NAD depletion: their relation to the turnover of endogenous mono (ADP-ribosyl) and poly (ADP-ribosyl) proteins. J. Biol. Chem. 257(21):12872-12877.

38. Sims, J. L., S. L. Berger, and N. A. Berger. 1983. Poly (ADPribose) polymerase inhibitors preserve nicotinamide adenine dinucleotide and adenosine 5'-triphosphate pools in DNA-damaged cells. mechanism of stimulation of unscheduled DNA synthesis. Biochemistry. 22:51885194.

39. Wielckens, K., E. George, T. Pless, and H. Hilz. 1983. Stimulation of poly (ADP-ribosyl)ation during Ehrlich ascites tumor cell "starvation" and suppression of concomitant DNA fragmentation by benzamide. $J$. Biol. Chem. 258(7):4098-4104.

40. Shall, S. 1984. Inhibition of DNA repair by inhibition of nuclear ADP-ribosyl transferase. In DNA repair and its inhibition. A. Collins, C. S. Downes, and R. T. Johnson, editors. Nucleic Acids Symp. Ser., Vol. 13. IRL Press, Oxford.

41. Malik, N., M. Miwa, T. Sugimura, P. Thraves, and M. Smulson. 1983. Immunoaffinity fractionation of the poly (ADP-ribosyl)ated domains of chromatin. Proc. Nat. Acad. Sci. USA. 80:2554-2558.

42. Butt, T. R., and M. Smulson. 1980. Relationship between nicotinamide adenine dinucleotide concentration and in vitro synthesis of poly(adenosine diphosphate ribose) on purified nucleosomes. Biochemistry. 19:5235-5242.

43. Nduka, N., C. J. Skidmore, and S. Shall. 1980. The enhancement of cytotoxicity of $N$-methyl- $N$-nitrosourea and gamma-irradiation by inhibitors of poly-ADP-ribose polymerase. Eur. J. Biochem. 105:525-533.

44. Skidmore, C. J., M. I. Davies, P. M. Goodwin, H. Halldorsson, P. J. Lewis, S. Shall, and A. A. Zia'ee. 1979. The involvement of polyADP-ribose polymerase in the degradation of NAD caused by gammairradiation and N-methyl-N-nitrosourea. Eur. J. Biochem. 101:135-142.

45. Berger, N. A. 1985. Symposium: cellular response to DNA damage: the role of poly (ADP-ribose). Rad. Res. 101:4-15.

46. Whish, W. J. D., M. I. Davies, and S. Shall. 1975. Stimulation of poly (ADP-ribose) polymerase activity by the anti-tumor antibiotic, streptozotocin. Biochem. Biophys. Res. Commun. 65:722.

47. Smulson, M. E., P. Schein, D. W. Mullins, and S. Sudhakar,
1977. A putative role for nicotinamide adenine dinucleotide-promoted nuclear protein modification in the antitumor activity of $N$-methyl- $N$ nitrosourea. Cancer Res. 37:3006-3012.

48. Yamamoto, H., Y. Uchigata, and H. Okamoto. 1981. Streptozotocin and alloxan induce DNA strand breaks and poly (ADP-ribose) synthetase in pancreatic islets. Nature (Lond.) 294:284-286.

49. Rankin, P. W., M. K. Jacobson, V. R. Mitchell, and D. L. Busbee. 1980. Reduction of nicotinamide adenine dinucleotide levels by ultimate carcinogens in human lymphocytes. Cancer Res. 40:1803-1807.

50. Seto, S., C. J. Carrera, M. Kubota, D. B. Wasson, and D. A. Carson. 1985. Mechanism of deoxyadenosine and 2-chlorodeoxyadenosine toxicity to non-dividing human lymphocytes. J. Clin. Invest. 75: 377-383.

51. Berger, N. A., G. W. Sikorski, S. J. Petzold, and K. K. Kurohara. 1979. Association of poly(adenosine diphosphoribose) synthesis with DNA damage and repair in normal human lymphocytes. J. Clin. Invest. 63:1164-1171.

52. Friedberg, E. C. 1985. DNA damage tolerance in eukaryotic cells. In DNA Repair. W. H. Freeman and Co., NY. 459-504.

53. Weitzman, S., and T. Stossel. 1982. Effects of oxygen radical scavengers and antioxidants on phagocytic induced mutagenesis. J. Immunol. 128(6):2770-2772.

54. Lewis, J. G., and D. O. Adams. 1985. Induction of 5,6-ringsaturated thymine bases in NIH-3T3 cells by phorbol ester-stimulated macrophages: role of reactive oxygen intermediates. Cancer Res. 45: 1270-1275.

55. Weitzman, S., A. B. Weitberg, E. P. Clark, and T. P. Stossel. 1985. Phagocytes as carcinogens: Malignant transformation produced by human neutrophils. Science (Wash. DC). 227:1231-1233.

56. Harlan, J. M., J. D. Levine, K. S. Callahan, B. R. Schwartz, and L. A. Harker. 1984. Glutathione redox cycle protects cultured endothelial cells against lysis by extracellularly generated hydrogen peroxide. J. Clin. Invest. 73:706-713.

57. Johnstone, A. P., and G. T. Williams. 1982. Role of DNA breaks and ADP-ribosyl transferase activity in eukaryotic differentiation demonstrated in human lymphocytes. Nature (Lond.). 300:368-370.

58. Berger, N., J. Adams, G. Sikorski, S. Petzold, and W. T. Shearer. 1978. Synthesis of DNA and poly (adenosine diphosphate ribose) in normal and chronic lymphocytic leukemia lymphocytes. J. Clin. Invest. 62:111-118.

59. Holtlund, J., T. Kristensen, A. C. Ostwald, and S. G. Laland. 1983. ADP-ribosylation in permeable HeLa S3 cells. Eur. J. Biochem. 130:47-51.

60. Rubin, R., and J. L. Farber. 1984. Mechanisms of the killing of cultured hepatocytes by hydrogen peroxide. Arch. Biochem. Biophys. 228:450-459.

61. Cerutti, P. A. 1985. Prooxidant states and tumor promotion. Science (Wash. DC). 227(4685):375-378. 